\title{
The occurrence of the ciguatera fish poisoning producing dinoflagellate genus Gambierdiscus in Pakistan waters
}

\author{
Sonia Munir ${ }^{1, *}$, P. J. A. Siddiqui ${ }^{1}$ and Steve L. Morton ${ }^{2}$ \\ ${ }^{1}$ Centre of Excellence in Marine Biology, University of Karachi, Karachi 75270, Pakistan \\ ${ }^{2}$ National Oceanic Atmospheric and Administration, Marine Biotoxins Program, 219 Fort Johnson Road, Charleston, \\ SC 29412, USA
}

Five benthic species of the genus Gambierdiscus (Dinophyceae) were observed for the first time in the coastal waters of Pakistan, Northern Indian Ocean. The morphology of the epiphytic, ciguatera-related toxic species G. toxicus, G. belizeanus, G. polynesiensis, G. australes and G. cf. yasumotoi are presented here, described by the Kofoid system of thecal plates Po, 3', 7", 6c, 8s, 5"', 1p, 2"' with differences in cell shape, cell size, plates, pores around the apical pore plate by using light and scanning electron microscopy. The occurrence of these potentially toxic dinoflagellate species in Pakistani coastal areas of Manora Channel and Balochistan during high temperatures of $28-32^{\circ} \mathrm{C}$ is cause of concern for human health impacts from ciguatera fish poisoning.

Key Words: ciguatera fish poisoning; Dinophyceae; Gambierdiscus; Northern Indian Ocean; Pakistan

\section{INTRODUCTION}

The primary causative agent of ciguatera fish poisoning (CFP) are nonplanktonic dinoflagellates of the genus Gambierdiscus (Dinophyceae). The type species is G. toxicus Adachi et Fukuyo 1979, an armored, unicellular, photosynthetic and toxic dinoflagellate species distributed circumtropically. This benthic dinoflagellate's preferred habitat is attached to macroalgae surface, algal turf, detritus, and sand (Bomber et al. 1988, Bagnis et al. 1990, Morton and Faust 1997, Masó et al. 2003, Aligizaki and Nikolaidis 2008). Gambierdiscus is an important species complex that produce ciguatoxins which cause of the CFP in the coral reef areas. CFP had been troublesome in island countries where human populations rely on reef fish as a primary protein source. Ciguatera is a syndrome that causes gastrointestinal, neurological and cardiovascular disorders in humans (Lewis et al. 1988, Palafox and
Buenconsejo-Lum 2001). Worldwide an estimated 50,000 people suffer every year from cigutera toxicity (Ragelis 1984, Anderson et al. 2000).

Species level description are very difficult for anteriposterior compressed dinoflagellate cells such as G. toxicus (Adachi et Fukuyo 1979), G. belizeanus (Faust 1995), G. australes, G. polynesiensis, G. pacificus (Chinain et al. 1999), G. carolinianus, G. caribaeus, G. carpenteri (Litaker et al. 2009) as well as globular shaped cells such as $G$. yasumotoi (Holmes 1998) and G. ruetzelri (Litaker et al. 2009). Distingushing these two groups depend upon the ornamentation and shape and size of plates.

The first case of CFP in Indian Ocean was described in Mauritius, an island in the western Indian Ocean (Quod and Turquet 1996). This is first observation of the Cigutara species from the northern part of the Indian Ocean, Paki- (c) This is an Open Access article distributed under the terms of the Creative Commons Attribution Non-Commercial License (http://creativecommons.org/licenses/by-nc/3.0/) which permits unrestricted non-commercial use, distribution, and reproduction in any medium, provided the original work is properly cited.
Received September 21, 2011, Accepted November 22, 2011

* Corresponding Author

E-mail: soniaku2003@yahoo.com

Tel: +92-21-9261397, Fax: +92-21-9261398 




Fig. 1. Coastal map of Pakistan. The sampling points along the Manora Channel coast of Karachi and Churna Island coast of Balochistan are marked by arrows.

stan is described according to modern taxonomical classification following Faust (1995), Holmes (1998), Chinain et al. (1999), Litaker et al. (2009). This study provides basic information about the toxic benthic dinoflagellates from the non-coral area of Manora Channel with high mangrove vegetation along the Karachi coast and the Coral reef area of the Balochistan coast Pakistan.

\section{MATERIALS AND METHODS}

\section{Sampling collection}

Samples sites were the Manora Channel Sindh coast of Karachi and Churna Island Balochistan coast. The Sindh coastline is about $250 \mathrm{~km}$ long and the continental shelf deep stretches into the ocean and adjacent to southereastern part to Indian border along Sir Creek on the east. The Balochistan coast is $800 \mathrm{~km}$ long with a steep and narrow continental shelf to the Iranian border near Jiwani in the west. These coastal areas are commercially important and provide a transit trade port via Karachi harbor and Gawader port of Balochistan.

Samples were collected from Manora Channel

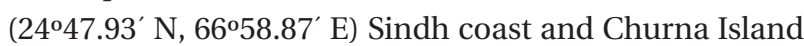
$\left(24^{\circ} 46.70^{\prime} \mathrm{N}, 66^{\circ} 26.66^{\prime} 40^{\prime \prime}\right.$ E) Balochistan coast of Pakistan (Fig. 1). The samples from the Manora channel were collected with a $55 \mu \mathrm{m}$ mesh size net during July 2007 and a Niskin bottle (1.7 L) sampler at $1 \mathrm{~m}$ depth from the Churna Island, Balochistan coast during November 2007. The water temperatures from both locations were $32^{\circ} \mathrm{C}$ and $28^{\circ} \mathrm{C}$, respectively.

\section{Microscopy techniques}

Samples were preserved in Lugols solution and brought to the Marine Biotoxin lab, USA and examined under 5600LV Scanning electron microscopy (JOEL, Tokyo, Japan) and under light microscopy / Fluorescence microscopy (BX51; Olympus, Tokyo, Japan) with a DP71 camera. Cells were stained with calcoflour white, examined under the 200-400x and images were captured with camera. For scanning electron micrograph, Lugol's fixed sample were desalted in seawater gradient $(100,70,50$, and $25 \%)$ and cleaned with $100 \%$ freshwater, dehydrated in an acetone series $(10,30,60,80$, and $100 \%)$, mounted and sputter coated with gold-platinum (Desk IV; Denton Vacuum, Moorestown, NJ, USA). The morphometric analysis was performed using Microsuite 5 (Olympus).

\section{RESULTS}

Five species of Gambierdiscus were present in the coastal waters of Pakistan, including. G. toxicus, G. belizeanus, G. polynesiensis, G. australes and G. cf. yasumotoi. Identification was based on Kofoidean thecal plate tabulation and structure (Yasumoto et al. 1977, Faust 1995, Holmes 1998, Chinain et al. 1999, Litaker et al. 2009).

\section{Gambierdiscus toxicus Adachi and Fukuyo 1979 (Figs 2A-H, 3A-C, 4A \& B)}

Cells of G. toxicus are round, flattened and dorsoventrally compressed in apical and antapical view. Cell size was 71.0-96.4 $\mu \mathrm{m}$ dorsoventrally and 61.9-90.1 $\mu \mathrm{m}$ in transdiameter. Both epitheca and hypotheca valves are smooth, porose and similar in height. The epitheca is ellipsoidal, compressed in apical view. Epithecal plates are comprised of 11 plates from pore plate to precingular plates as apical pore plate $(\mathrm{Po}), 3^{\prime}, 7^{\prime \prime}$ are variable in shape and size (Fig. 2D \& F). The Po is fish hooked shaped and is 7.7-8.0 $\mu \mathrm{m}$ long and 4.4-6.1 $\mu \mathrm{m}$ wide. The oval shaped Po covered with dense pores openings $(\mathrm{n}=28-30)$ is positioned at the ventral side of the apical plate (Figs 2F, 3A $\& B)$. The first apical plate, $1^{\prime}$, is small, pentagonal and is seven sided at the left corner of epitheca and edge of $1^{\prime \prime}$ and 7" plates of precingular plates, connected with Po, 2', $3^{\prime}, 6^{\prime \prime}, 7^{\prime \prime}, 1^{\prime \prime}$, and $2^{\prime \prime}$. The $2^{\prime}$ is a sub rectangular plate, much broader and larger that is $41.1-45.8 \mu \mathrm{m}$ long and 13.3-27.2 


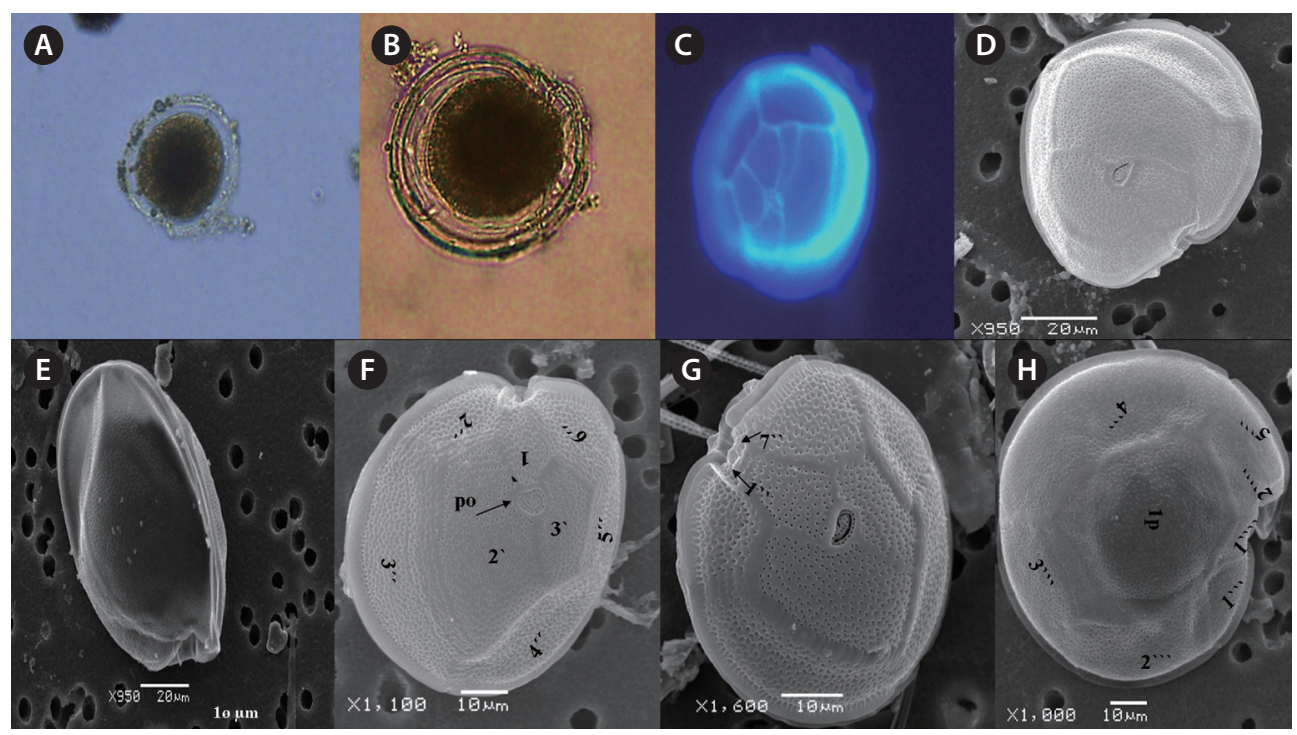

Fig. 2. Gambierdiscus toxicus. (A-C) Light microscopy and fluorescence stained cells. (D-H) Scanning electron micrograph of the anteriorposterior compressed surface, the flattened shaped, and the smooth thecal surface. (F) Epithecal plates and fish hook shape (Po) (black arrow) in apical view. (G) The 1", 7" small precingular plates (black arrows). (H) Postcingular plates and posterior intercalary plate (1p) in antapical view.

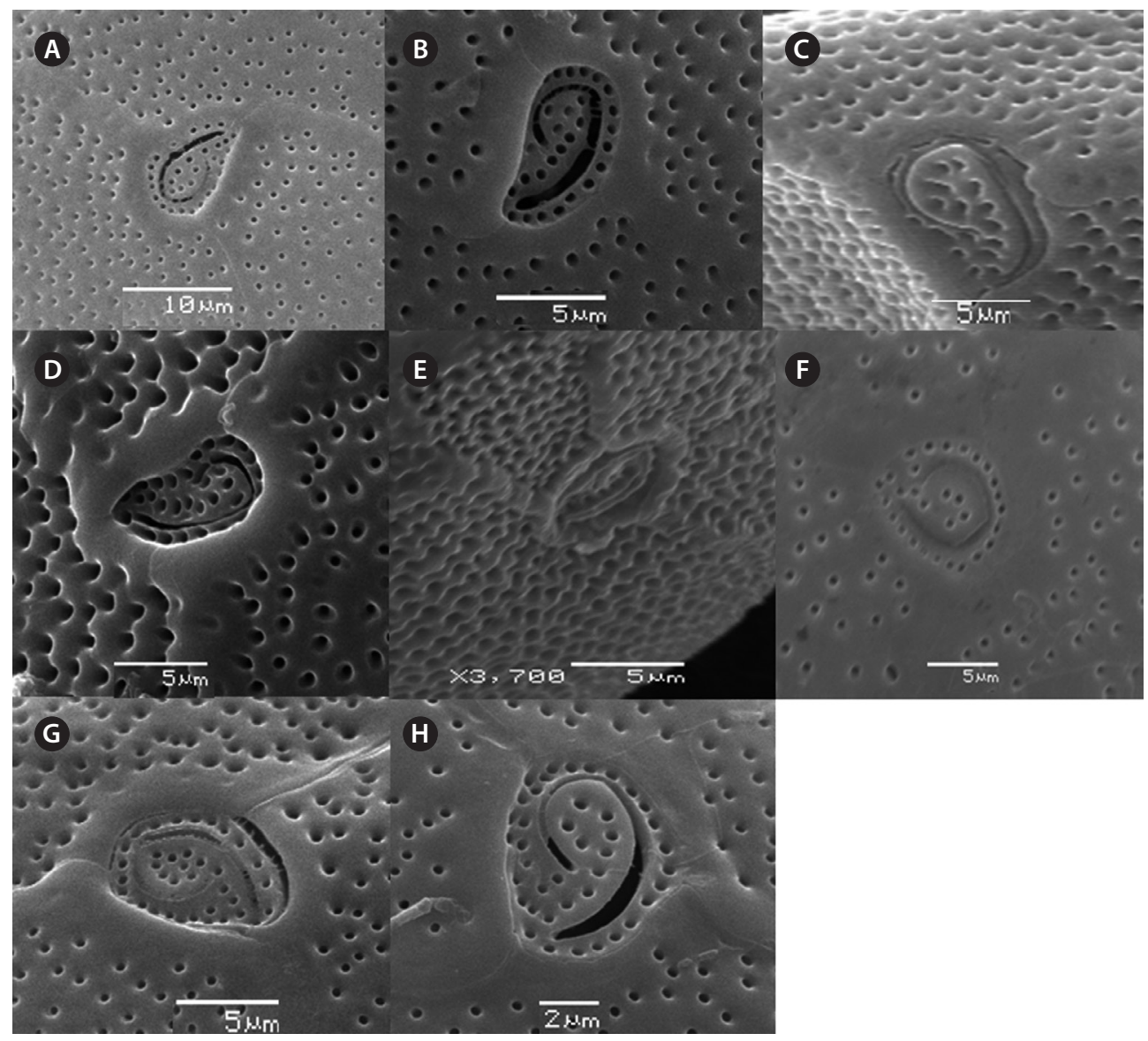

Fig. 3. Scanning electron microscopy of apical pore plates. (A-C) Tear shaped apical plate with apical pores of Gambierdiscus toxicus. (D \& E) Apical plate of rugose G. belizeanus. (F) Apical plate of G. australes. (G \& H) Triangle shaped apical plate of G. polynesiensis. 


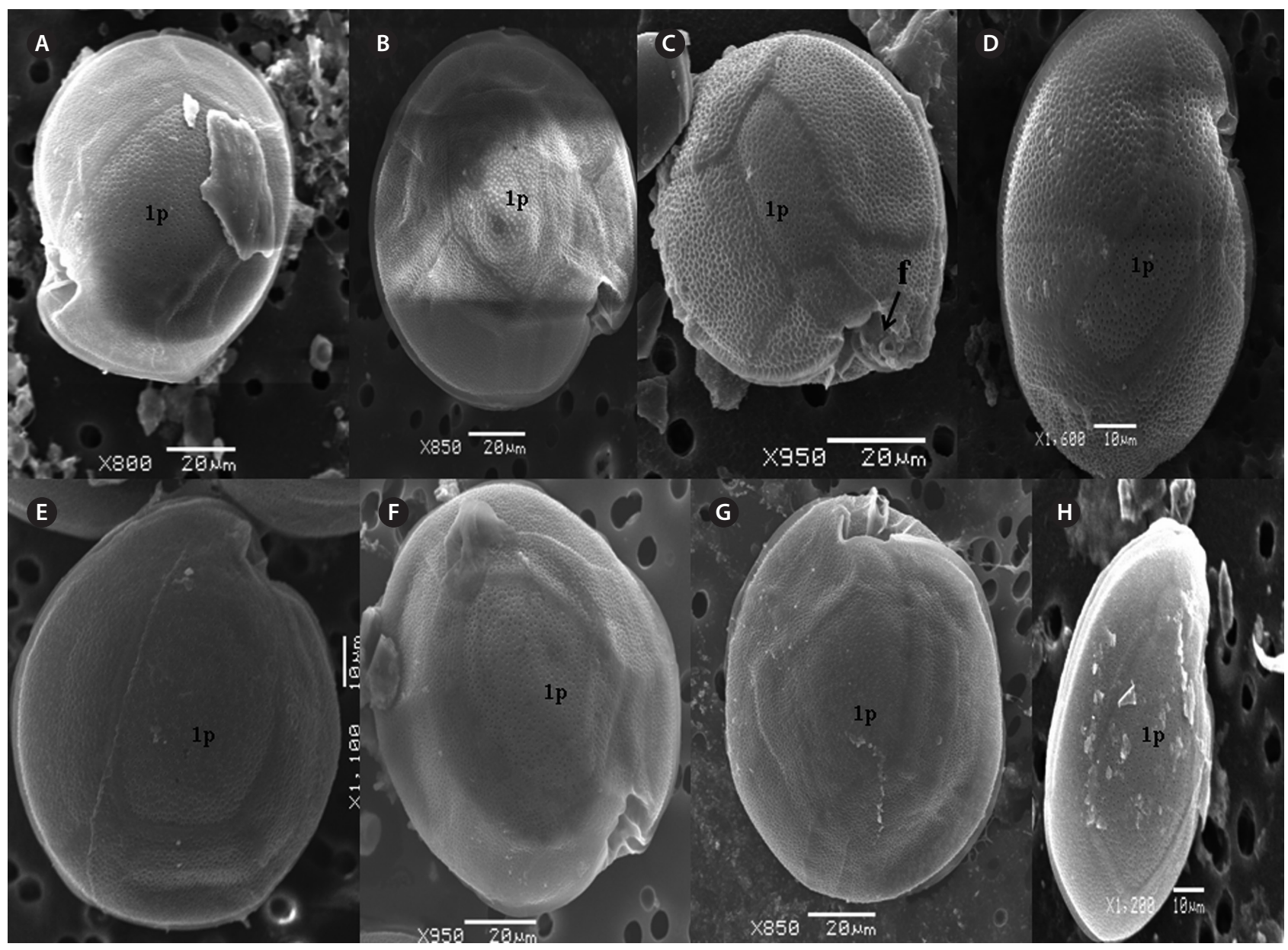

Fig. 4. Scanning electron micrograph of posterior intercalary plates (1p). (A \& B) Gambierdiscus toxicus. (C \& D) G. belizeanus. (E \& F) G. australes. (G \& H) G. polynesiensis.

$\mu \mathrm{m}$ wide, comes in contact with $2^{\prime \prime}, 3 "$, and $4 "$ plates. Of the precingular plates, $1^{\prime \prime}$ and 7 " are smallest, and 3 " much larger 51.3-68.8 $\mu \mathrm{m}$ and 8.0-14.5 $\mu \mathrm{m}$ in wide (Fig. $2 \mathrm{~F} \& \mathrm{G}$ ).

The hypotheca is more excavated with eight plates ( 5 "', $1 \mathrm{p}$, and $\left.2^{\prime \prime \prime \prime}\right)$. The postcingular plate $4 "$ is large $32.5-54.0$ $\mu \mathrm{m}$ and 13.8-23.5 $\mu \mathrm{m}$ wide. The $1^{\prime \prime \prime \prime}$ and $2^{\prime \prime \prime}$ plates are small

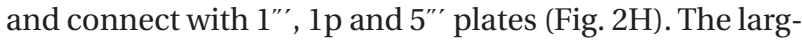
est plate is a posterior intercalary plate (1p) that is 45.3$59.6 \mu \mathrm{m}$ long and 13.8-23.5 $\mu \mathrm{m}$ wide (Figs $2 \mathrm{H}, 4 \mathrm{~A} \& \mathrm{~B}$ ).

\section{Gambierdiscus belizeanus Faust 1995 (Fig. 5, A-E)}

Cells of G. belizeanus are round, and dorso-ventrally compressed in apical and antapical view. Sizes ranged from 53.6-74.7 $\mu \mathrm{m}$ dorsoventrally and 65.1-68.9 $\mu \mathrm{m}$ in transdiameter. The epitheca and hypotheca surface are aerolated with equally distributed dense pores. The epitheca is ellipsoidal, compressed in apical view and composed of 11 plates e.g., Po, 3', and 7" (Fig. 5A \& B). The Po is fish hooked shaped and is 7.7-8.0 $\mu \mathrm{m}$ long and 4.6-6.1 $\mu \mathrm{m}$ wide and covered with dense pores $(n=30)$ positioned ventrally with the $1^{\prime}, 2^{\prime}$, and 3 ' plates (Figs 3D, E, 5B \& C). The first apical plate $1^{\prime}$ is small , pentagonal, seven sided, located in the left corner of epitheca, and connected with Po, $2^{\prime}, 3^{\prime}, 6^{\prime \prime}, 7^{\prime \prime}, 1^{\prime \prime}$ and $2^{\prime \prime}$. The $2^{\prime}$ is sub rectangular that is much broader and larger 39.6-40.0 $\mu \mathrm{m}$ long and 17.0-18.8 $\mu \mathrm{m}$ wide and has wide contact with $2 ", 3$ " and 4 " plates. Of the precingular plates, $1^{\prime \prime}$ and $7 "$ are the smallest and $3 "$ is much longer 39.2-59.6 $\mu \mathrm{m}$ and 10.0-15.0 $\mu \mathrm{m}$ wide, but smaller between the $4 "$ and $5 "$, and $6 "$. The sulcus is short, deeply concave oriented to the right (Fig. 5B).

The hypotheca is more excavated consisting of eight plates (5"', 1p, and 2"') (Fig. 5D). The postcingular 4"' is elongated and 40.1-49.9 $\mu \mathrm{m}$ long and 18.8-24.7 $\mu \mathrm{m}$ wide. The $5^{\prime \prime \prime}$ is the smallest plate, and $1^{\prime \prime \prime \prime}$ and $2^{\prime \prime \prime}$ are located along the edge of the $5^{\prime \prime}, 11^{\prime \prime}$ and $1 p$ plates (Fig. 5D). The curved end of the cingular list at the sulcus forms a chamber like opening (Fig. 5D \& E). The largest posterior $1 p$ is 




Fig. 5. Gambierdiscus belizeanus. (A-C) Scanning electron micrographs of epithecal plates with precingular plates and the apical pore (Po) (black arrow). (D) Hypothecal plates in antapical view with postcingular and intercalary plate (1p). (D \& E) Sulcus list as chamber like opening marked by the white arrow.

27.7- 33.1 $\mu \mathrm{m}$ long and 11.7-14.6 $\mu \mathrm{m}$ wide (Figs 4C, D \& $5 \mathrm{D})$.

\section{Gambierdiscus australes Faust et Chinain} (Fig. 6, A-D)

The cell is round, ellipsoid and compressed dorsoventrally in apical view. The epitheca and hypotheca are smooth. Cell size is $60.0-81.6 \mu \mathrm{m}$ in dorsoventral diameter and 48.3-75.8 $\mu \mathrm{m}$ in transdiameter. The epithecal plates are Po, 3', 7" and hypothecal plates are (5"', $1 \mathrm{p}$, and $2^{\prime \prime \prime \prime}$ ) (Fig. 6B \& D). The Po is broadly ellipsoid, fish hooked shaped and small 5.4-6.4 $\mu \mathrm{m}$ long and 4.31-5.2 $\mu \mathrm{m}$ wide surrounded by 31 pores oriented ventrally (Figs $3 \mathrm{~F} \& 6 \mathrm{C}$ ). The apical plate 2 ' is longer 41.3-46.6 $\mu \mathrm{m}$ and wider 23.4$27.8 \mu \mathrm{m}$ than those of the $1^{\prime}$ and $3^{\prime}$ plates. The precingular plates $\left(1^{\prime \prime}-7^{\prime \prime}\right)$ has $4 "$ and $3^{\prime \prime}$ plates that are larger than 1", $2 ", 5 ", 6$ ", and 7" plates. The cingulum is deep, narrow and consists of Fig. 6C cingular plates and a cingular list (Fig. $6 \mathrm{~B})$.

The sulcus consists of eight sulcul plates. The hypothecal plates $1^{\prime \prime \prime \prime}$ and $2^{\prime \prime \prime \prime}$ are smaller in series and $4^{\prime \prime \prime}$ is a large plates 31.5-35.7 $\mu \mathrm{m}$ long and 12.6-13.4 $\mu \mathrm{m}$ wide in the postcingular plate series. The $1 \mathrm{p}$ plate is long and narrow 25.3-45.2 $\mu \mathrm{m}$ long and 17.7-31.0 $\mu \mathrm{m}$ wide (Figs $4 \mathrm{E}, \mathrm{F} \& 6 \mathrm{D}$ ) and contacts the $2{ }^{\prime \prime \prime}, 3^{\prime \prime \prime}, 44^{\prime \prime}$ plates. The $5^{\prime \prime \prime}$ and 1"' are the smallest plates and positioned close to the cingulum (Fig. $6 \mathrm{D})$.

\section{Gambierdiscus polynesiensis Chinain et Faust (Fig. 7, A-D)}

The cell is round, ellipsoid and compressed dorsoventrally in apical view. Both thecae are smooth and convex. Cell size is 65.1-88.6 $\mu \mathrm{m}$ dorsoventral and 56.5-75.0 $\mu \mathrm{m}$ in transdiameter. Epithecal plates Po, $3^{\prime}, 7^{\prime \prime}$ have a differently 


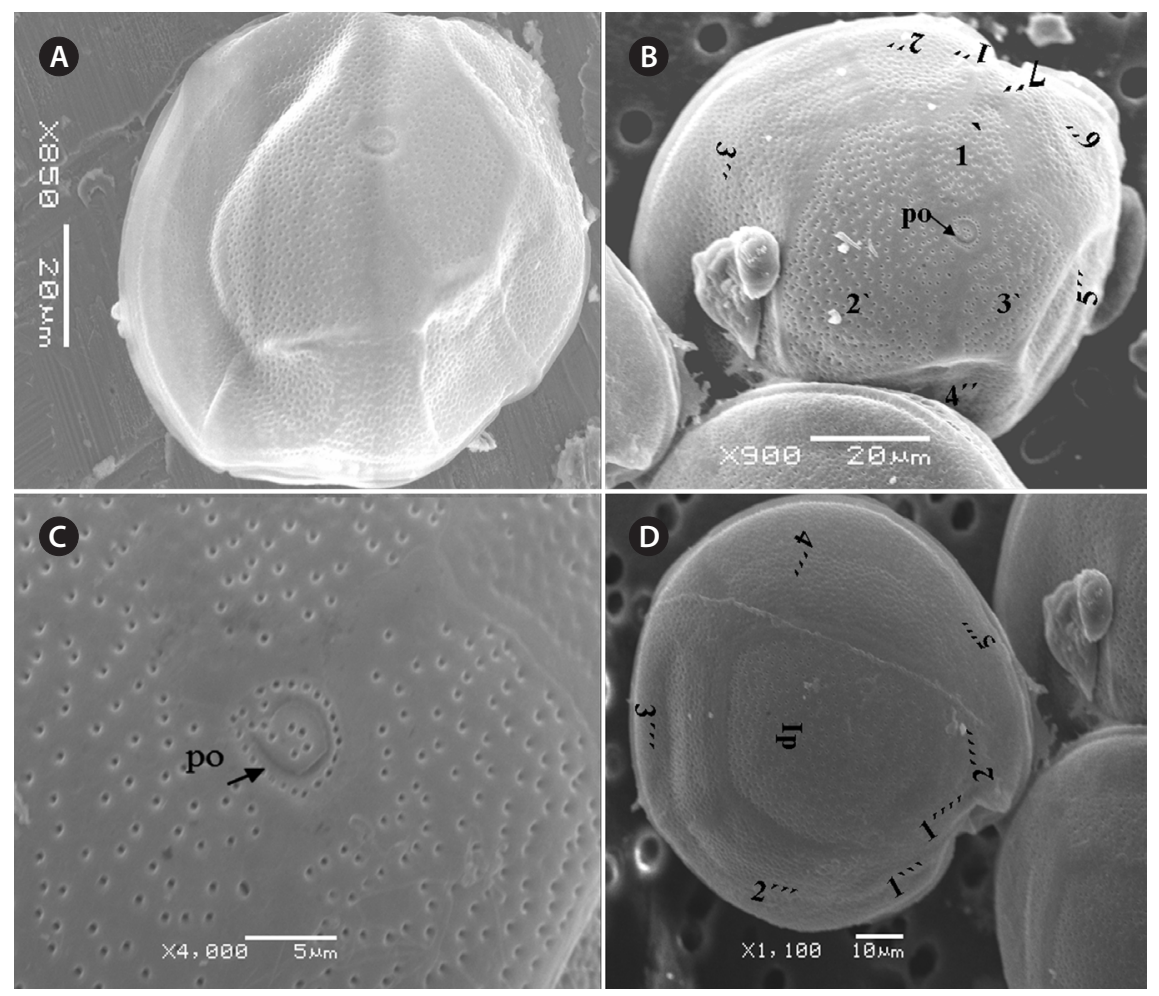

Fig. 6. Gambierdiscus australes. (A-D) Scanning electron micrographs of precingular plates 1' to 7" with apical pore plate (Po) (black arrow). (C) Broadly shaped fish hook apical plate (Po) with apical pores (black arrow). (D) Postcingular plates (1"' to 5"') and intercalary plate (1p) in antapical view.
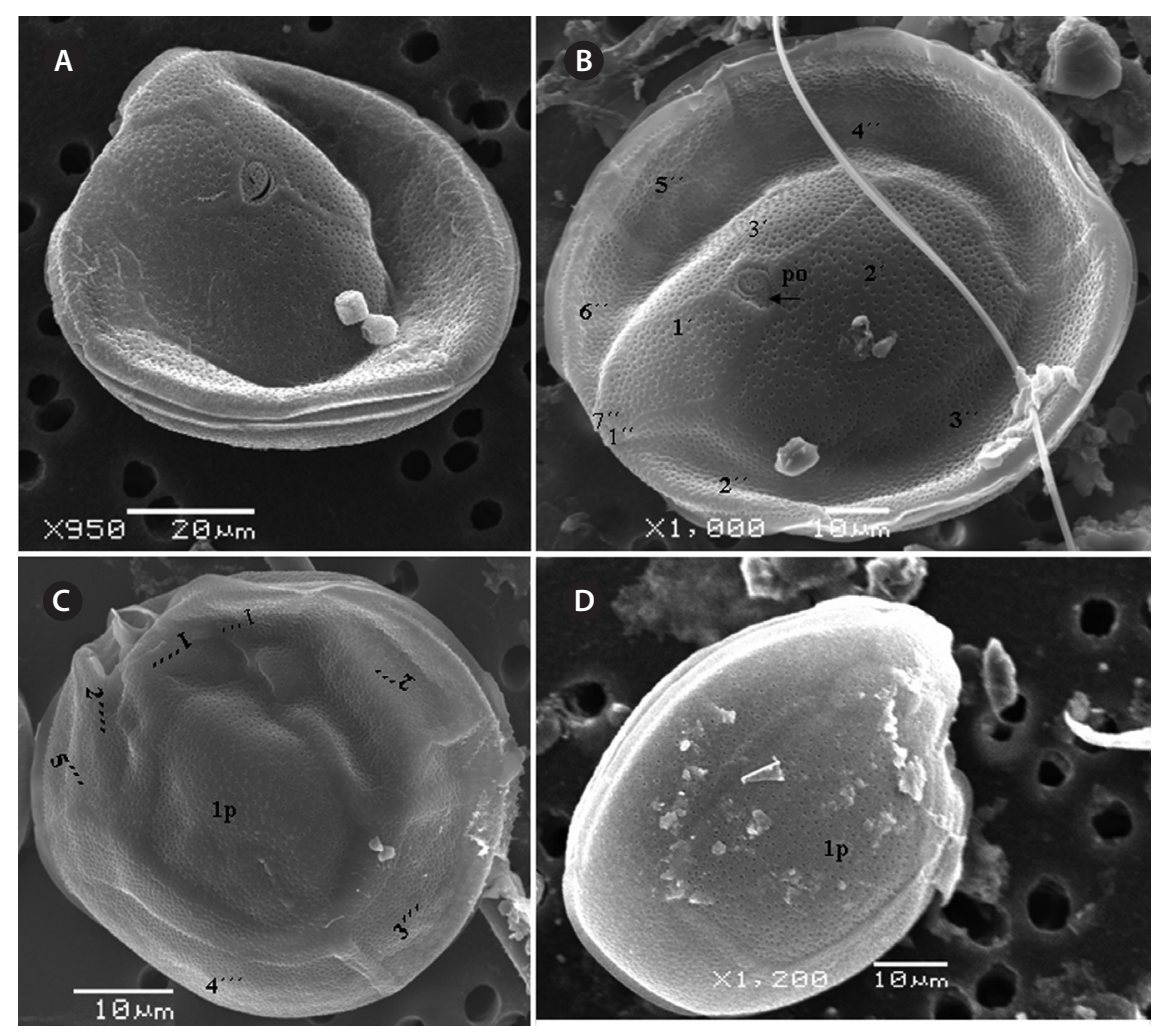

Fig. 7. Gambierdiscus polynesiensis. (A-D) Scanning electron micrographs. (B) Epithecal plates with triangular shaped apical pore plate (Po) (black arrow). (C \& D) Hypothecal plates or postcingular plates with broad intercalary plate (1p). 


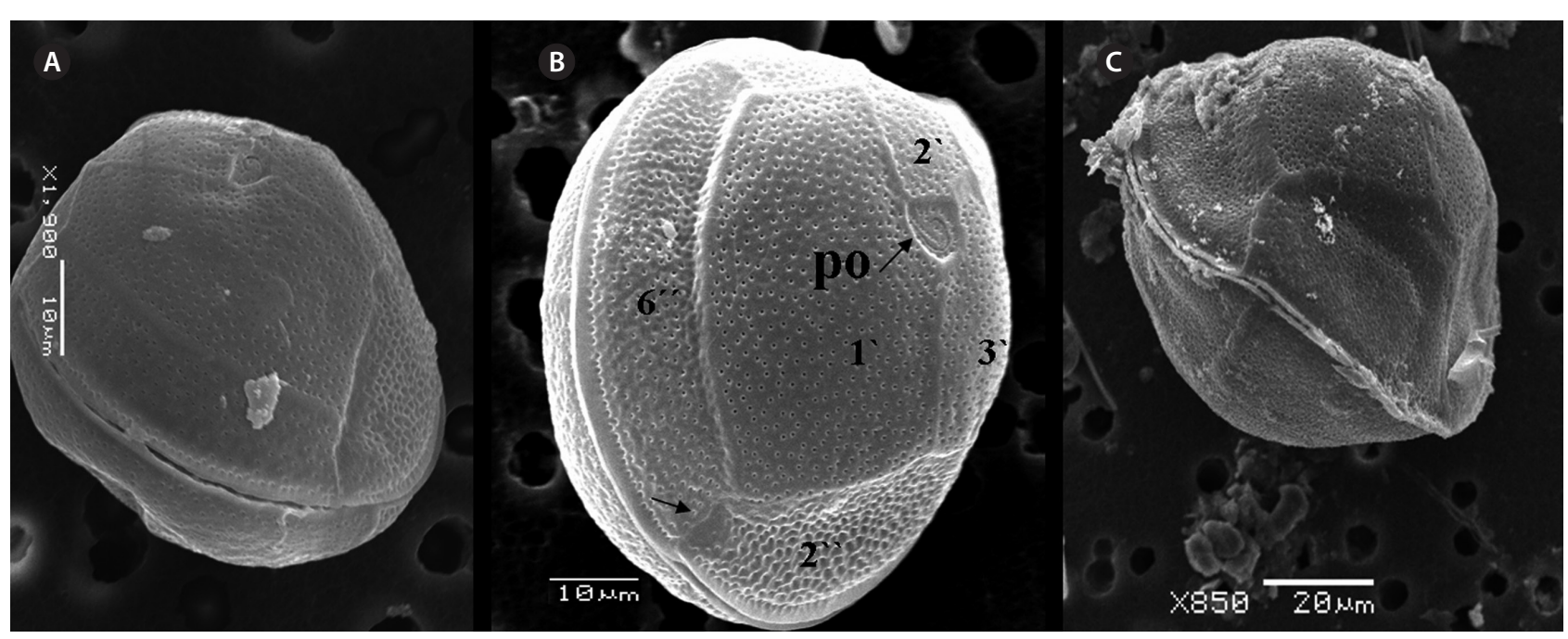

Fig. 8. Gambierdiscus cf. yasumotoi. (A-C) Scanning electron micrographs, globular shaped epitheca in apical view. (B) A groove like structure present at the precingular plate (black arrows). Cingular list is lipped and curved with marginal pores. Po, apical pore plate.

triangular shaped Po that is 7.1-8.6 $\mu \mathrm{m}$ long and 5.7-6.2 $\mu \mathrm{m}$ wide, oriented ventrally, and surrounded by 38 pores (Figs 3G, H \& 7B). The apical pore $2^{\prime}$ is a plate $45.2-48.2$ $\mu \mathrm{m}$ long and $25.8-26.8 \mu \mathrm{m}$ wide. The precingular plates, seven in number, run counterclockwise just below the $1^{\prime}$ and consist of the $4 "$ and $3 "$, which are the largest plates and $2^{\prime \prime}, 5 "$, and $6 "$ which are the same size, and $1 "$ and 7", which are the smallest (Fig. 7B).

The hypothecal plates are $5^{\prime \prime \prime}, 1 \mathrm{p}$ and 2"'" (Fig. 7C). The $1^{\prime \prime \prime}$ plates are smaller in a series positioned parallel to the $1 p$ plate at a dorsoventral axis wheareas $2^{\prime \prime \prime \prime}$ is larger than that of $1^{\prime \prime \prime \prime}$. The 4 "' is a large plate, $60.0 \mu \mathrm{m}$ long and 18.4 $\mu \mathrm{m}$ wide, and the $1 \mathrm{p}$ plate is broad, pentagonal, $46.2 \mu \mathrm{m}$ long and $35.5 \mu \mathrm{m}$ wide (Figs $4 \mathrm{G}, \mathrm{H}, 7 \mathrm{C} \& \mathrm{D}$ ) and contacts the 2"', 3 "' and 4"'. The 5 "' and 1"' are smallest and positioned close to the cingulum.

\section{Gambierdiscus cf. yasumotoi Holmes 1998} (Fig. 8, A-C)

Cell is globular shaped in apical view. The thecal surface is smooth with numerous pores. Cell size is 49.25$51.93 \mu \mathrm{m}$ long and 43.21-51.4 $\mu \mathrm{m}$ wide. The Po is fish hooked shaped is 4.7-7.7 $\mu \mathrm{m}$ long and 4.2-5.2 $\mu \mathrm{m}$ wide and positioned centrally, and connected with the $3^{\prime}, 2^{\prime}$ and 1' plates (Fig. 8A-C). The precingular plates are seven in number and $6^{\prime \prime}$ is the largerest precingular plate and $1 "$ and $7 "$ are the smallest. A small depression is present, enclosed by a small list from the sulcus to the right suture of the 1" plate (Fig. $8 \mathrm{~B}$ ). The cingulum is lipped, covered with a row of marginal pores (Fig. 8B \& C).

\section{DISCUSSION}

This is the first report on the potentially toxin producing species of the genus Gambierdiscus from the northern part of Indian Ocean, coast of Pakistan. Previous phytoplankton studies off the Pakistani coast by Ghazala et al. (2006) recorded 79 different species of dinoflagellates without any genera, which may be misidentified as Gambierdiscus. To date, five species of Gambierdiscus including G. toxicus, G. belizeanus, G. australes, G. polynesiensis, G. cf. yasumotoi have been identified along the Pakistan coast. Gambierdiscus species in the present study were observed in a planktonic survey from the non-coral area, Manora Channel and coral reef area, Balochistan coast of Pakistan. To date, the only observation of the genus Gambierdiscus from the Indian Ocean is from the Reunion Island. These cells were identified by Litaker et al. (2009) as Gambierdiscus toxicus. The species of Gambierdiscus found in this study is a mixture of species found only in the Atlantic (G. belizeanus) and the Pacific (G. polynesiensis and G. australes).

Toxic dinoflagellate species are a diverse population in the Indian Ocean along the adjacent areas of Indian and Pakistan. Many of potentially toxic species have been collected in the areas where $50-90 \%$ corals had died or the turf covered coral reefs area. This is common throughout much of the region in Indian Ocean such as shallow reefs in Seychelles, Comoros, Madagascar and Chagos and reefs areas in the Gulf of Mannar, Gulf of katuch, Andaman and Lakshadweep Island (Quod 1999, Rajasuriya et al. 1999). Only small coral patches were found in turbid 
areas of Pakistan (Rajasuriya et al. 1999) but very little information has been available on the coral habitat in Pakistan coastal area especially the Astola and Churna Island along the Balochistan coast (Siddiqui et al. 2008). No research is available regarding corals from Sindh coast of Karachi, which is highly influenced by pollutants, sewage and domestic water from freshwater inlet of the Layri River.

During phytoplankton net sampling on the Karachi coast, only G. belizeanus, G. cf. yasumotoi and G. toxicus were observed in mangrove vegetation at Sandspit area while G. polynesiensis, G. australes, and G. toxicus were observed Niskin bottle samples collected along the Balochistan coast, which is known for coral biodiversity. During this plankton sampling, a few numbers of cells $(\mathrm{n}=$ 3 to 15) were analyzed for taxonomy. It should be noted that macroalgae are the preferred habitat for these benthic dinoflagellates therefore this study drastically underestimated the possible ecological relevance of these species. This is a preliminary report on the presence of Gambierdicus species from this region to alert fisheries departments and resource managers. This research report will provide a foundation for new research projects with emphasis on the abundance of these benthic species and impacts on fish community structure. A clear need exists to develop practical database techniques for data archiving and analysis to promote regional assessments in biophysical and fishery areas that will be developed a link as socio-economic and biophysical research to understand the status of these toxic species and economic activity. The most important issue for management and public awareness is to treat ciguatera fish poisoning and develop a management plan for reef fishes exported from Pakistan.

\section{ACKNOWLEDGEMENTS}

This research was supported by the foreign scholarship program (IRSIP, 2008) Higher Education Commission, Islamabad, Pakistan to S. Munir work in Hollings Marine Laboratory, United States of America.

\section{REFERENCES}

Adachi, R. \& Fukuyo, Y. 1979. The thecal structure of a marine toxic dinoflagellate Gambierdiscus toxicus gen. et sp. nov. collected in a ciguatera endemic area. Bull. Jpn. Soc. Sci. Fish. 45:67-71.
Aligizaki, K. \& Nikolaidis, G. 2008. Morphological identification of two tropical dinoflagellates of the genera Gambierdiscus and Sinophysis in the Mediterranean Sea. J. Biol. Res. Thessalon. 9:75-82.

Anderson, D. M., Hoagland, P., Kaoru, Y. \& White, A. W. 2000. Estimated annual economic impacts from Harmful Algal Blooms (HABs) in the United States. WHOI-2000-11. Woods Hole Oceanographic Institution, Woods Hole, MA, 97 pp.

Bagnis, R., Legrand, A. M. \& Inoue, A. 1990. Follow-up of a bloom of the toxic dinoflagellates Gambierdiscus toxicus on a fringing reef of Tahiti. In Graneli, E., Sundstrom, B., Edler, L. \& Anderson, D. M. (Eds.) Toxic Marine Phytoplankton. Elsevier, New York, pp. 98-103.

Bomber, J. W., Morton, S. L., Babinchak, J. A., Norris, D. R. \& Morton, J. G. 1988. Epiphytic dinoflagellates of drift algae: another toxigenic community in the Ciguatera food chain. Bull. Mar. Sci. 43:204-214.

Chinain, M., Faust, M. A. \& Pauillac, S. 1999. Morphology and molecular analyses of three toxic species of Gambierdiscus (Dinophyceae): G. pacificus, sp. nov., G. australes, sp. nov., and G. polynesiensis, sp. nov. J. Phycol. 35:12821296.

Faust, M. A. 1995. Observation of sand-dwelling toxic dinoflagellates (Dinophyceae) from widely differing sites, including two new species. J. Phycol. 31:996-1003.

Ghazala, B., Ormond, R. \& Hannah, F. 2006. Phytoplankton communities of Pakistan: I. Dinophyta and Bacillariophyta from the coast of Sindh (Pakistan). Int. J. Phycol. Phycochem. Pak. 2:183-196.

Holmes, M. J. 1998. Gambierdiscus yasumotoi sp. nov. (Dinophyceae), a toxic benthic dinoflagellate from southeastern Asia. J. Phycol. 34:661-668.

Lewis, R. J., Chaloupka, M. Y., Gillespie, N. C. \& Holmes, M. J. 1988. An analysis of the human response to ciguatera in Australia. In Choat, J. H., Barnes, D., Borowitzka, M. A., Coll, J. C., Davies, P. J., Flood, P., Hatcher, B. G., Hopley, D., Hutchings, P. A., Kinsey, D., Orme, G. R., Pichon, M., Sale, P. F., Sammarco, P., Wallace, C. C., Wilkinson, C., Wolanski, E. \& Bellwood, O. (Eds.) Proc. 6th. Int. Coral Reef Symp., Townsville, pp. 67-72.

Litaker, R. W., Vandersea, M. W., Faust, M. A., Kibler, S. R., Chinain, M., Holmes, M. J., Holland, W. C. \& Tester, P. A. 2009. Taxonomy of Gambierdiscus including four new species, Gambierdiscus caribaeus, Gambierdiscus carolinianus, Gambierdiscus carpenteri and Gambierdiscus ruetzleri (Gonyaulacales, Dinophyceae). Phycologia 48:344-390.

Masó, M., Garcés, E., Pagès, F. \& Camp, J. 2003. Drifting plastic debris as a potential vector for dispersing Harmful 
Algal Bloom (HAB) species. Sci. Mar. 67:107-111.

Morton, S. L. \& Faust, M. A. 1997. Survey of toxic epiphytic dinoflagellates from Belizean barrier reef ecosystem. Bull. Mar. Sci. 61:899-906.

Palafox, N. A. \& Buenconsejo-Lum, L. E. 2001. Ciguatera fish poisoning: reviewof clinical manifestations. J. Toxicol. Toxin Rev. 20:141-160.

Quod, J. P. 1999. Consequences of the 1998 coral bleaching event for the islands of the western Indian Ocean. In Lindén, O \& Sporrong, N. (Eds.) Coral Reef Degradation in the Indian Ocean. CORDIO SAREC Marine Science Program, Stockholm, pp. 53-59.

Quod, J. P. \& Turquet, J. 1996. Ciguatera in Reunion Island (SW Indian Ocean): epidemiology and clinical pattens. Toxicon 34:779-785.
Ragelis, E. P. 1984. Ciguatera seafood poisoning: overview. In Ragelis, E. P. (Ed.) Seafood Toxins. American Chemical Society, Washington, D.C., pp. 25-36.

Rajasuriya, A., Maniku, M. H., Subramanian, B. R. \& Rubens, J. 1999. Coral reef ecosystems in South Asia. In Lindén, O \& Sporrong, N. (Eds.) Coral Reef Degradation in the Indian Ocean. CORDIO \& SAREC Marine Science Program, Stockholm, pp. 10-23.

Siddiqui, P. J. A., Farooq, S., Shafique, S., Burhan, Z. -U. -N. \& Farooqi, Z. 2008. Conservation and management of biodiversity in Pakistan through the establishment of marine protected areas. Ocean Coast. Manag. 51:377-382.

Yasumoto, T., Nakajima, I., Bagnis, R. A. \& Adachi, R. 1977. Finding of a dinoflagellate as a likely culprit of Ciguatera. Bull. Jpn. Soc. Sci. Fish. 43:1021-1026. 